\title{
A LINGUAGEM POÉTICA NA SALA DE AULA
}

Gisela Maria de Lima Braga Penha

Universidade Federal do Acre - Brasil

\section{RESUMO}

O presente artigo pretende apresentar um possível caminho para trabalhar a linguagem poética em sala de aula. A perspectiva metodológica, aqui adotada, levará a questão artística como primordial no trato da literatura, pois, trata-se de uma prática semiológica, cuja ótica plurissêmica envolve aspectos diversos da relação texto-receptor-contexto para mobilizar os possíveis efeitos de sentidos gerados pelo signo estético. Ao considerar o texto literário em seu componente estético, pretendemos demonstrar que é justamente por meio dessa estrutura plurissêmica que encontraremos diversos caminhos para trabalhar a linguagem poética com o objetivo de aproximar o aluno ao texto literário.

PALAVRAS-CHAVE: Teoria da literatura. Linguagem poética. Ensino.

Quando alguém diz: sou professor de literatura, a primeira pergunta que é feita é: "mas ensinar literatura para quê?" "Qual a utilidade do estudo de poesia?" Poderíamos pensar que essa visão é de alguém fora do sistema educacional, cujo olhar está direcionado a outros objetivos não necessariamente educacionais. No entanto, e se essa pergunta fosse feita por um professor? Ou em uma hipótese mais alarmante: e se esse questionamento fosse feito como forma de negar a existência do ensino de literatura em nossas escolas?

Em um primeiro momento, isso pareceria impossível. No entanto, infelizmente, esse quadro já é possível de ser visto em nossa realidade educaciona ${ }^{1}$. Há professores de Língua Portuguesa que, por razões diversas, deixam de lado o ensino de literatura em suas salas de aula e priorizam outros conteúdos. Nosso objetivo não é discutir o que leva um docente a excluir determinado conteúdo e suas possíveis razões para fazê-lo, mas apontar para este fato que não é tão incomum quanto parece à primeira vista.

Em 2011, realizamos duas pesquisas de Iniciação Científica ${ }^{1}$ no

1 Estas pesquisas de Iniciação Científica foram realizadas com recursos de bolsa PI- 
CAP- Colégio de Aplicação da UFAC, situado na cidade de Rio Branco, Acre, com alunos da $1^{\mathrm{a}}, 2^{\mathrm{a}}$ e $3^{\mathrm{a}}$ séries do Ensino Médio. O objetivo era dar minicursos de literatura com uma proposta metodológica diferenciada, embasada em projeto de pesquisa cujo foco é estabelecer uma ligação entre a Teoria da literatura e a sala de aula.

Diferentes resultados foram obtidos: na $1^{\mathrm{a}}$ e $2^{\mathrm{a}}$ séries, houve uma ótima recepção aos minicursos, tanto que esses alunos encenaram uma peça teatral a partir do estudo de Auto da barca do inferno, do escritor português Gil Vicente. $\mathrm{Na} 3^{\mathrm{a}}$ série, o resultado não atingiu o objetivo desejado, e serviu para refletirmos sobre outros aspectos em nossa pesquisa. No entanto, interessa-nos, aqui, a discussão acerca dos resultados positivos: o que foi feito para que os alunos tivessem interesse em uma peça portuguesa do começo do século XVI cuja linguagem é de difícil compreensão? O que os motivou a encená-la?

Várias razões podem ser apontadas para responder a tais perguntas, mas iremos enfatizar uma das possíveis respostas ligando-a ao objetivo deste artigo: atingimos nosso objetivo com os alunos da $1^{\mathrm{a}} \mathrm{e}$ $2^{\mathrm{a}}$ séries do CAP porque a metodologia utilizada foi eficiente e as ministrantes (duas alunas de Graduação de Letras Português da UFAC) foram eficazes como professoras. Apesar de terem trabalhado com um texto distante no tempo, no espaço, pertencente à outra cultura, houve uma ótima aceitação por parte dos alunos. Tal constatação nos permite dizer que o problema do ensino de literatura não está nos textos literários, mas justamente em dois componentes fundamentais a este segmento: a metodologia utilizada e o desempenho do professor, ou ainda, o ponto chave desta questão está na forma pela qual o texto é trabalhado pelo docente.

BIC/UFAC e receberam a permissão do Comitê de ética em pesquisa para a sua realização. (processos n n 23107.007196/2011-31 e no 23107.007197/2011-86). 
Existem muitos estudos que promovem discussões acerca deste problema. Ele é gravíssimo e deve ser objeto de reflexão em todos os segmentos de nossa sociedade. Parece-nos que este é, também, nosso trabalho como professores de curso de Licenciatura em Letras Português: como resgatar o espaço do ensino de literatura que, de uma maneira geral, encontra-se perdido, ou, no mínimo, sofre distorções de toda ordem.

Se os cursos de Licenciatura formam professores, parece-nos lógico que este segmento educacional tenha uma preocupação em relação ao tipo de professor que sairá para o mercado de trabalho. Neste sentido, é pertinente refletir sobre como trabalhar com a linguagem poética na sala de aula, pois essa é um dos maiores temores de professores, como pudemos verificar em nossas pesquisas.

Como já dissemos, para que o professor de literatura tenha êxito, é fundamental que ele utilize uma metodologia adequada a seu objeto de trabalho. Mas como conseguir isto? Uma das possibilidades de escolha metodológica faz-se a partir da "definição" do conceito de Literatura, visto que, como apontam os críticos e teóricos literários, esse é um conceito que comporta muitas definições, o que pode ser visto como um problema. No entanto, se a metodologia escolhida estiver embasada teoricamente, tal problema pode ser visto como solução, ou ainda, talvez seja o primeiro passo para que as aulas de literatura promovam efetivamente a aprendizagem. É também o caminho, para estabelecer a ligação necessária, embora às vezes negada, entre a Teoria da literatura, o texto literário e ensino.

Assim, levaremos em conta que literatura é arte. Nossa perspectiva metodológica para abordar o texto literário levará a questão artística como primordial no trato da literatura, o que demanda, ao contrário do que se costuma pensar, uma prática ampla e densa de procedimentos. Para dizermos mais adequadamente, trata-se de uma 
prática semiológica, cuja ótica plurissêmica envolve aspectos diversos da relação texto-receptor-contexto para mobilizar os possíveis efeitos de sentidos gerados pelo signo estético.

Lotman (1978, p.25) faz uma importante constatação:

Ao longo de toda a existência historicamente estabelecida da humanidade, a arte é o seu companheiro de viagem. Em diferentes etapas da história, ouviu-se periodicamente levantarem-se vozes contra a inutilidade da arte, mesmo contra a sua nocividade. No entanto, nesta luta, todas as vitórias se mostraram quiméricas: a arte renascia invariavelmente sobrevivendo aos seus detractores (LOTMAN, 1978, p.25).

Para o semioticista, a arte "não representa uma parte da produção e a sua existência não é condicionada pela exigência do homem de renovar incessantemente os meios de satisfazer as necessidades materiais". Sem ser atrelada ao imediatismo, nem ao pragmatismo das relações sociais obrigatórias, a arte tem uma "necessidade essencial", no dizer de Lotman.

Se a arte em geral pode ser vista como inútil, tal visão também se relaciona à literatura, e se pensarmos no texto poético, o problema fica maior. Não é por acaso que a crítica e professora universitária Leyla Perrone-Moisés publicou o livro Inútil poesia (2000), cujo título pode ser visto como uma grande ironia se levarmos em conta que os artigos contêm uma declaração indireta de amor à literatura e suas inúmeras possibilidades de significação. No artigo: "Consideração intempestiva sobre o ensino de literatura" (2000, p.345-351) ela afirma: "A literatura, tal como a entendemos desde o início da modernidade, não é ensinável. Mas a leitura literária não apenas pode ser ensinada como necessita de uma aprendizagem, e é por isso que os professores de literatura ainda existem" (PERRONE-MOISÉS, 2000, p. 350).

Mais à frente, a pesquisadora diz: 
O mestre da crítica brasileira, Antonio Candido, fez uma vez uma conferência na qual defendia o direito à literatura como um dos direitos humanos. Isso me parece não apenas verdadeiro, mas oportuno como tática. No momento atual, em que todos pretendem defender alguma causa minoritária, a defesa de uma disciplina tão ameaçada é uma boa causa que os professores de "literatura literária", essa corporação quase extinta, deveriam adotar. Segundo Antonio Candido, a literatura deve ser ensinada porque atua como organizadora da mente e refinadora da sensibilidade, como oferta de valores num mundo onde eles se apresentam flutuantes (PERRONE-MOISÉS, 2000, p.351).

Assim, como pudemos verificar, embora haja visões negativas acerca da literatura e suas funções, e neste sentido ela seria é considerada inútil, parece-nos, devemos não só refletir acerca dessas colocações, mas também, nos posicionarmos ativamente, pois só assim essas questões terão respostas consistentes.

As funções da literatura são variadas e diversas: representação, expressão, intervenção e transformação da sociedade, conhecimento. Octavio Paz, em seu livro antológico, O arco e a lira, nos apresenta uma definição que contempla as inúmeras significações da linguagem poética:

Operação capaz de transformar o mundo, a atividade poética é revolucionária por natureza: exercício espiritual, é um método de libertação interior (...). Súplica ao vazio, diálogo com a ausência, é alimentada pelo tédio, pela angústia e pelo desespero. Oração, litania, epifania, presença. Exorcismo, conjuro, magia. Sublimação, compensação, condensação do inconsciente. Expressão histórica das raças, nações, classes (PAZ, 1982, p.15).

Como, enquanto professor de "literatura literária", trabalhar com um objeto que, em um primeiro momento, nos parece enigmático, hermético e avesso a decifrações superficiais? Propomos que é justamente por meio de suas próprias características que o texto poético deve ser trabalhado em sala de aula, o que pode parecer simples, mas não é. 
Desde nossa infância, de um modo geral, temos contato com construções linguísticas cuja ênfase está na ludicidade da linguagem. Assim temos os trava-línguas, por exemplo: "o rato roeu a roupa do rei de Roma, a rainha com raiva resolveu remendar"; "Num ninho de mafagafos, cinco mafagafinhos há! Quem os desmafagafizá-los, um bom desmafagafizador será" e outros tantos. Há ainda as cantigas de roda, como: "Samba Lelê está doente/está com a cabeça quebrada/ Samba Lelê precisava/de umas dezoito lambadas/Samba, samba, Samba ô Lelê/pisa na barra da saia ô Lalá; ou ainda o popular "Atirei o pau no gato". As cantigas de ninar também apresentam esta característica lúdica: a famosa "Nana neném", "Boi da cara preta" entre outras. As cantigas populares trabalham com essa mesma estrutura. "A canoa virou" serve como modelo para mostrarmos o jogo feito com as palavras.

O ser humano gosta também de onomatopeias, palavras imitativas, isto é, as que procuram reproduzir certos sons ou ruídos. Por exemplo: coisa quebrando: Crás! Tiro: Bang! Batendo na madeira ou em uma porta: Toc Toc; trovões: Cabrum!

Mas quais as possíveis relações entre esses textos de cunho popular e a linguagem poética, que, de um modo geral, fica distante da sala de aula? Se nos atentarmos para os textos populares acima descritos, veremos que os primeiros estão construídos a partir de aliterações, assonâncias, rimas, anáforas, figuras que buscam estabelecer, por meio do trabalho com o som, uma ligação seja de cunho semântico, seja como busca de ludicidade. Alfredo Bosi (1993) afirma:

A linguagem humana é pensamento-som, conforme a expressão feliz de Saussure. Mas nem o pensamento nem o som se comunicam por si mesmos: aparecem, para o homem em sociedade, já reunidos em articulações que se chamam signos. A rigor, dentro da teoria de Saussure, nada há de verbal aquém da síntese pensamento-som, nem além dela. O som em si e o pensamento transcendem a língua. No entanto, a experiência de cada um de nós diz que a poesia vive 
em estado de fronteira. Como a Matemática. No poema, força-se o signo para o reino do som (grifos nossos). No teorema, o signo é repuxado para as convenções do intelecto (BOSI, 1993, p.39).

Não está aí, uma das possíveis ligações entre a temida linguagem poética presente em poemas e os textos populares? Não podemos, por meio dessa característica em comum, aproximar os textos literários de nossos alunos? Esses recursos sonoros não criam ritmos tão humanos quanto a linguagem?

O grande poeta mineiro Carlos Drummond de Andrade utiliza frequentemente o recurso da repetição para conseguir criar seus poemas. Um dos mais conhecidos é "No meio do caminho":

No meio do caminho tinha uma pedra

Tinha uma pedra no meio do caminho

Tinha uma pedra

No meio do caminho tinha uma pedra.

Nunca me esquecerei desse acontecimento

$\mathrm{Na}$ vida de minhas retinas tão fatigadas.

Nunca me esquecerei que no meio do caminho

Tinha uma pedra

Tinha uma pedra no meio do caminho

No meio do caminho tinha uma pedra (ANDRADE, 1996, p. 56).

É bem fácil perceber que a repetição, inversão e retomada do verso "no meio do caminho tinha uma pedra" criam o poema e todas as suas possibilidades de significação. O signo pedra pode ser entendido metaforicamente: como obstáculo, empecilho, problema a ser transposto por alguém ao longo de sua existência. Mas, talvez, o recurso mais surpreendente, talvez por sua aparente simplicidade, está na repetição sistemática do verso que faz com que tenhamos a noção de que as "pedras" ao longo de nosso caminho aparecerão tão frequentemente quanto estão repetidas no poema. Não está aí, um aprofundamento dos recursos sonoros das cantigas de roda, de ninar, tão populares em 
nossa sociedade? Assim, consideramos que, ao demonstrar para os alunos, a ligação existente entre o trabalho de construção dos textos considerados populares e a literatura, por muitos, considerada erudita, conseguiremos aproximar da vida do aluno algo considerado distante e sem sentido, ou ainda, inútil.

A leitura do poema de Drummond também nos permite fazer uma ligação entre som e sentido: quando há a inversão do verso-título do poema, como na primeira estrofe, e nos últimos versos da segunda estrofe, a leitura também "trava", fica mais difícil e temos que prestar bastante atenção para não haver equívocos quando pronunciamos as palavras. Portanto, temos a iconização de pedra como metáfora de obstáculo. Ao ritmo da leitura perpassa a pedra drummondiana. Octavio Paz nos ajuda a elucidar esta questão: "A célula do poema, seu núcleo mais simples, é a frase poética. Porém, diferentemente do que acontece com a prosa, a unidade de frase, o que a constitui como tal e forma a linguagem, não é o sentido ou direção significativa, mas o ritmo" (1982, p. 61).

Assim, parece-nos extremamente produtiva a aproximação e ligação entre textos considerados populares, como forma introdutória, para fazer com que os textos literários tornem-se próximos e façam sentido para os alunos. Ao professor caberá a tarefa de adequar os textos selecionados em relação à faixa etária dos discentes.

Mas qual seria o objetivo de aproximar o texto literário de nossos alunos? Ou em outras palavras: literatura para quê? Antoine Compagnon, professor de literatura na França e nos Estados Unidos, proferiu uma palestra em 2006 com esse mesmo título. A conferência foi publicada em livro e podemos, por meio dele, ter algumas respostas e reflexões. Ele afirma: "Hoje, quando vivemos um desequilíbrio na escola tão decisivo quanto a reviravolta de 1902, afetando não mais a 
cultura clássica e as línguas antigas, mas a cultura moderna e a língua francesa, é o conhecimento literário que nos impõe defender" (COMPAGNON, 2012, p.35). Este é também, nosso objetivo. Mas a questão ainda permanece: defender por quê?

Novamente recorreremos a Octavio Paz "O poeta encanta a linguagem por meio do ritmo. Ele é inseparável de um conteúdo concreto. Ambos são a mesma coisa. O ritmo não é a medida - é visão do mundo" (1982, p. 67). Se ligarmos essa visão às forças da literatura propostas por Roland Barthes em seu antológico Aula (2007): mimesis, mathesis e semiosis, respectivamente, o poder de representação de mundo, o lugar onde os saberes se encontram e sua imensa capacidade de criar significações, verão que, em última instância, o texto literário terá como foco o ser humano. Barthes afirma: "a literatura não diz que sabe alguma coisa, mas que ela sabe algo das coisas - que sabe muito sobre os homens" (grifos nossos) (BARTHES, 2007, p.18).

Esse parece ser um dos caminhos possíveis para o professor de literatura: trabalhar o texto literário enquanto construção estética a qual propicia a criação de plurissignificações e nos permite sentir ser, ou ainda na visão de Octavio Paz: "A poesia é entrar no ser" (1982, p.85).

\section{POETIC LANGUAGE IN THE CLASSROOM}

\section{ABSTRACT}

This paper presents a possible way to work poetic language classroom. The methodological approach, adopted here, take the question as artistic paramount in dealing with literature, because it is a practice semiology, whose optical involves various aspects of the relationship text-receptor-context to mobilize the possible effects of meanings generated by aesthetic sign. When considering the literary text in its aesthetic component, we intend to demonstrate that it is precisely through this structure we find many ways to work the poetic language with the goal of bringing the literary text the student.

KEYWORDS: Theory literature. Poetic language. Teaching 


\section{REFERÊNCIAS}

ANDRADE, C. D. Antologia poética. $35^{\text {a }}$. ed. Rio de Janeiro: Record, 1996.

BARTHES, R. Aula: aula inaugural da cadeira de semiologia literária do Colégio de França, pronunciada dia 7 de janeiro de 1977. 13.ed. São Paulo: Cultrix, 2007.

BOSI, A. O ser e o tempo da poesia. São Paulo: Cultrix, 1993. COMPAGNON, A. Literatura para quê? Belo horizonte: Editora da UFMG, 2009.

LOTMAN, Y. A estrutura do texto artístico. Estampa: Lisboa, 1978.

PAZ, O. O arco e a lira. Rio de Janeiro: Nova Fronteira, 1982. (Coleção Logos).

PERRONE-MOISÉS, L. Inútil poesia e outros ensaios breves. São Paulo: Companhia das Letras, 2000. 